\title{
MANUFACTURABILITY ASSESSMENT OF THE PRODUCT ASSEMBLY PROCESSES DESIGN IN THE AUTOMOTIVE INDUSTRY
}

The paper presents a methodology for the design of the production process of a new product from the point of view of manufacturability criterion assembly operations (Design for Assembly - DFA) in the automotive industry. Methods and techniques, used in implementation of the DFA method to produce a new product, are mentioned. Impact of those methods on improving the assembly technology of a complex product is described. Suggestions for improving the abovementioned methods are presented, as ell. The examples given illustrate the proposed procedures.

Keywords: production process design, design manufacturability

\section{Introduction}

In modern market conditions, enterprises, introducing new products and innovative solutions in production processes, use various methods and techniques to rationalize the activities that make up the concept of production preparation. The issue has extensive literature in which project management methods are presented and various approaches assessing the process of production preparation using the philosophy of Design for Six Sigma, Implementation of the quality function - QFD, Value engineering VE, Design for assembly/ design for production - DFA/DFM, Target Costing [1]. As a result of technical progress in the conditions of the large production volume, when implementing new products, relatively less attention is paid to ever-wider technological possibilities: modern workstations, workshop aids, automation - to achieve the high efficiency and relatively low costs of process components of the final production. Hence, the advanced methods, described in the literature for assessing the possibilities of manufacturing products, are oriented on assembly processes and are adapted to assess implementation of a new product in conditions of high volume and mass production.

This is due to the high proportion of manual work compared to machining, the significant share in the costs of the entire production process, the high labour intensity and high costs of the assembly process.

\section{Production preparation processes}

To describe the processes of mass production a new product implementation model is used, proposed by
AAIG (Automotive Action Industry Group - Automobile Manufacturers Association), described in the APQP manual - Advanced Product Quality Planning (Figure 1) [2-4].

There are many proposals in the automotive industry for use of the design-oriented assembly assessment methods. Design for Assembly - DFA, are described by G. Boothroyd and P. Dewhurst in [5]. The concept of Design for Assembly can be defined in a variety of ways, from the relatively narrow meaning of product design from the point of view of assembly technology criteria to the broader term associated with the term product design and process flow from the point of view of the cost-effective and reliable manufacturing criterion for ensuring customer satisfaction and achieving financial success [6]. Many DFA methods are presented in the literature. The chronology of these methods development and their brief description characterizing their use is presented in Table 1 [7].

The first two methods are presented in the paper due to the greatest practical application. Competition on the market forced companies to take a comprehensive approach to rationalizing the design and marketing of a new product [8-9]. This situation evoked the need for a broader view on the assessment of the technology of the structure, including this problem, considering many other aspects; this way of design is illustrated in Figure 2.

Other methods - QFD (Quality Function Deployment) [10-11] have also found application in the processes of designing products that complement or support the DFA methods. [11] - used to implement customer requirements in initial product assumptions, FMEA (Failure Mode and Effect Analysis) [12] - predicting and preventing product failure at the design stage, DFX (Design for X) [13-14] e.g. Design for Manufacturing (DFM) means the design

\footnotetext{
Jozef Matuszek ${ }^{1}$, Tomasz Seneta ${ }^{1}$, Luboslav Dulina ${ }^{1}$, Eleonora Bigosova ${ }^{2}$ *

${ }^{1}$ Katedra Inzynierii Produkcji, Wydzial Budowy Maszyn i Informatyki, Akademia Techniczno-Humanistyczna w Bielsku-Bialej, Poland ${ }^{2}$ Department of Industrial Engineering, Faculty of Mechanical Engineering, University of Zilina, Slovakia

*E-mail of corresponding author: eleonora.bigosova@fstroj.uniza.sk
} 


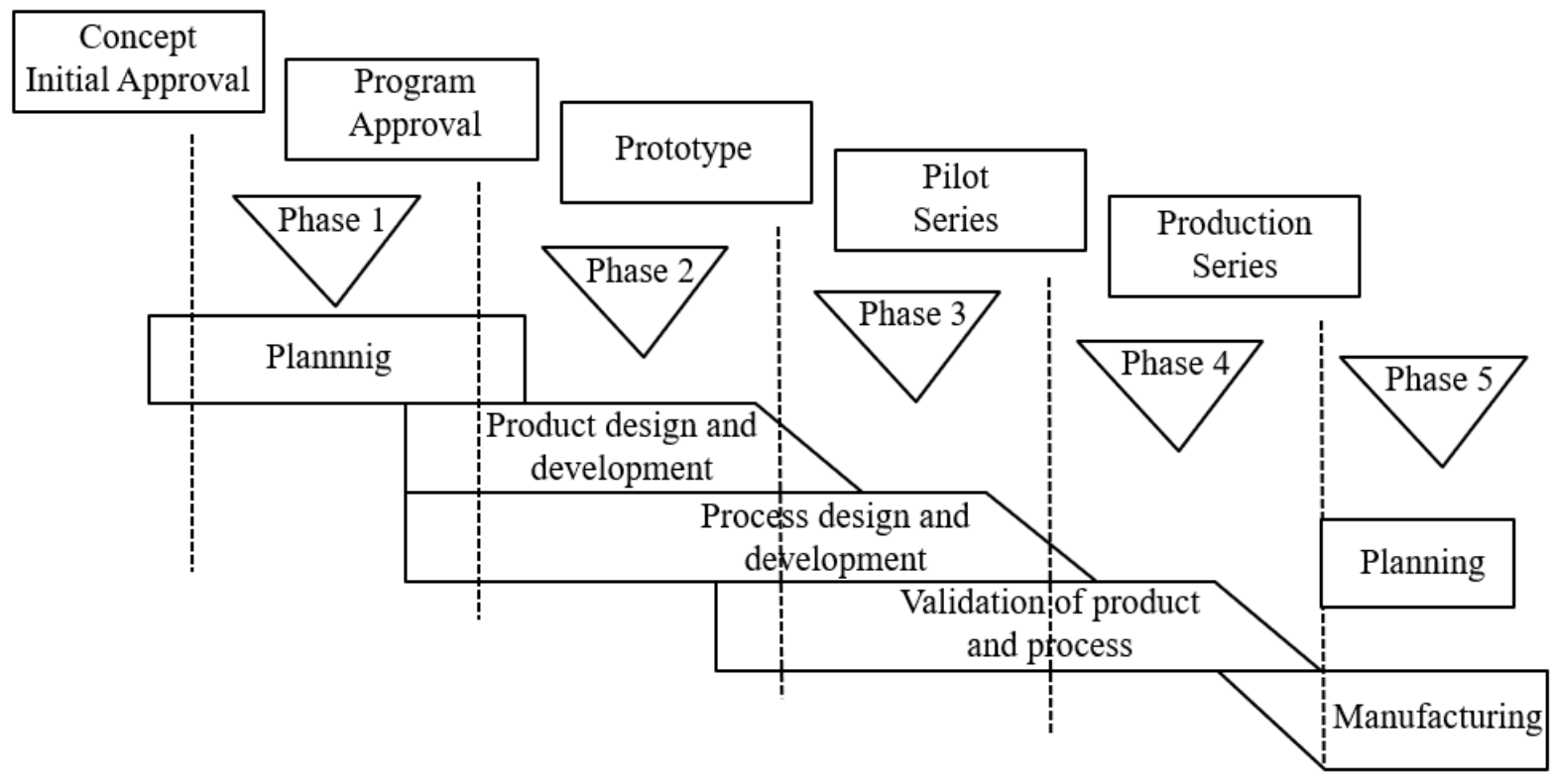

Figure 1 Model of implementing a new product according to AAIG [2-4]

Table 1 Summary and description of the methodology of selected Design of Assembly methods [1]

\begin{tabular}{|c|c|c|c|c|}
\hline $\mathrm{Nr}$ & Method & Year & Discoverers & Description \\
\hline 1 & Lucas DFA & 1980 & Redford A. H., Swift K. G. & $\begin{array}{c}\text { It is based on Assembly Sequence Diagram, } \\
\text { evaluating the assembly design. } \\
\text { Evaluates and adds penalty points } \\
\text { related to product } \\
\text { design issues. }\end{array}$ \\
\hline 2 & $\begin{array}{l}\text { Hitachi Assemblability } \\
\text { Evaluation Method (AEM) }\end{array}$ & 1986 & Miyagawa S., Ohashi T. & $\begin{array}{l}\text { This method evaluates the product's } \\
\text { assemblability and cost index to identify } \\
\text { weaknesses associated with } \\
\text { the project design. }\end{array}$ \\
\hline 3 & $\begin{array}{c}\text { Product Assemblability Merit } \\
\text { Analysis Tool (PDM) }\end{array}$ & 1986 & Zorowski C. F. & $\begin{array}{l}\text { The method issues opinions on product } \\
\text { and component assembly problems } \\
\text { and an oversizing indicator. }\end{array}$ \\
\hline 4 & Boothroyd and Dewhurst & 1988 & Boothroyd G., Dewhurst P. & $\begin{array}{l}\text { The method is based on an experimental } \\
\text { study of the costs associated with a manual } \\
\text { or automatic assembly process and has } \\
\text { three criteria for limiting the number } \\
\text { of components. }\end{array}$ \\
\hline 5 & $\begin{array}{c}\text { Integrated Design for Assembly } \\
\text { Evaluation and Reasoning } \\
\text { System }\end{array}$ & 1991 & $\begin{array}{l}\text { Sturges R. H. Jr, Kilani } \\
\text { M. I. }\end{array}$ & $\begin{array}{l}\text { The method built on the existing solid } \\
\text { modelling package examines the product's } \\
\text { assemblability. }\end{array}$ \\
\hline 6 & $\begin{array}{l}\text { Fuzzy Product Assemblability } \\
\text { Merit Analysis Tool }\end{array}$ & 1993 & $\begin{array}{l}\text { Jackson S. D., Sutton J. C., } \\
\text { Zorowski C. F. }\end{array}$ & PDM developed with fuzzy logic. \\
\hline 7 & DFA REV-ENGE & 1994 & Kim G. J., Bekey G. A. & $\begin{array}{l}\text { DFA method considering reverse } \\
\text { engineering. }\end{array}$ \\
\hline 8 & Constraints Network System & 1995 & $\begin{array}{l}\text { Oh J. S., Grady P. O., } \\
\text { Young R. D. F. }\end{array}$ & The method of related restrictions. \\
\hline 9 & Virtual Disassembly Evaluation & 1998 & Srinivasan H. & Method considering virtual disassembly. \\
\hline
\end{tabular}

of many structural elements that shape the production process [15-16]. These methods are related to concepts, such as simultaneous engineering, Six Sigma, Lean, WCM (World Class Manufacturing) and others. Decisions taken at the product design stage do not have a significant impact on production costs only, but on the production efficiency and quality, as well. Supporting methods such as modelling are of great importance in carrying out these works, simulation and animation of production processes and systems and ideas stimulating innovation such as brainstorming, TRIZ (Theory of solving innovative tasks) and others. 


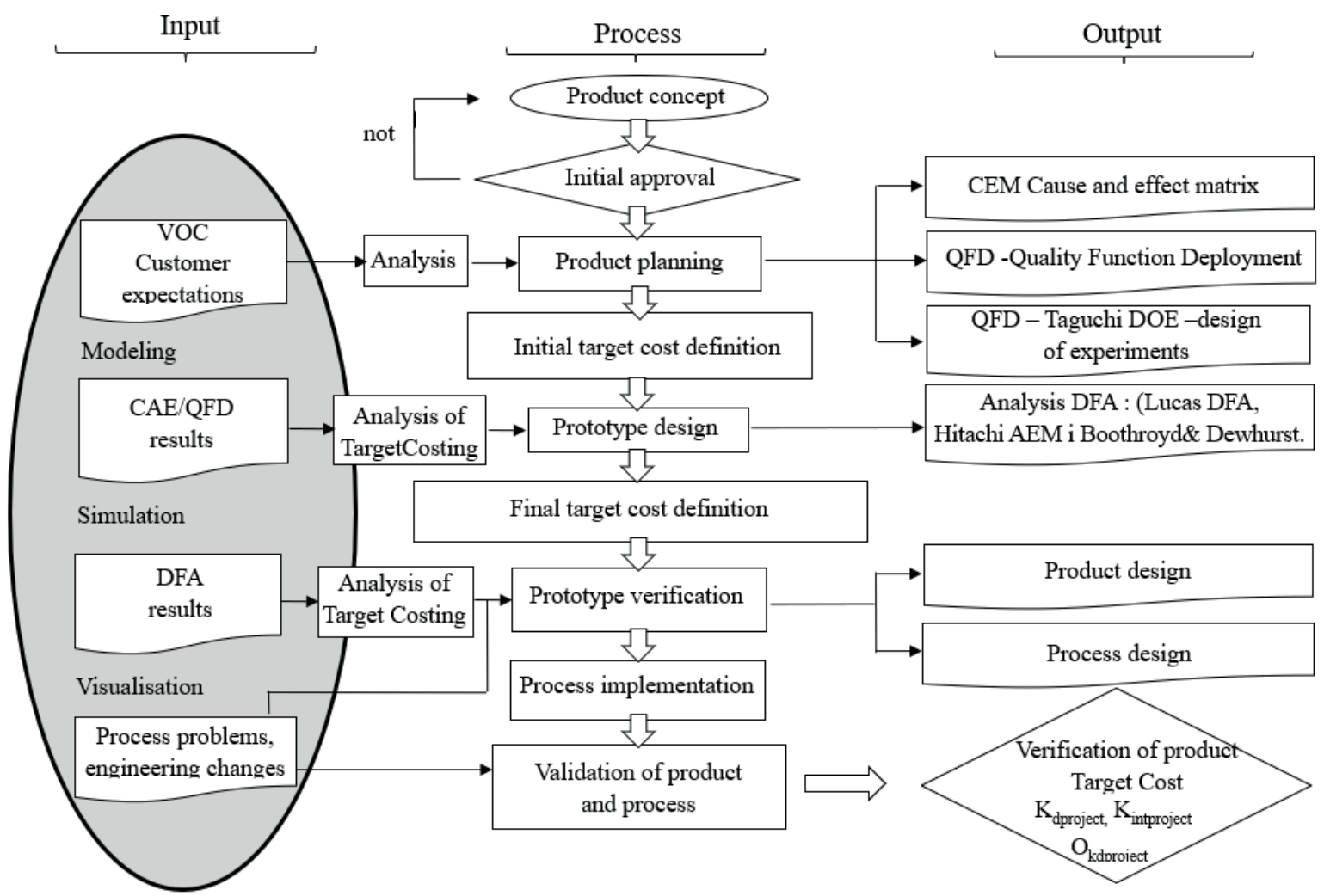

Figure 2 Use of methods supporting the design of the production process of a new product

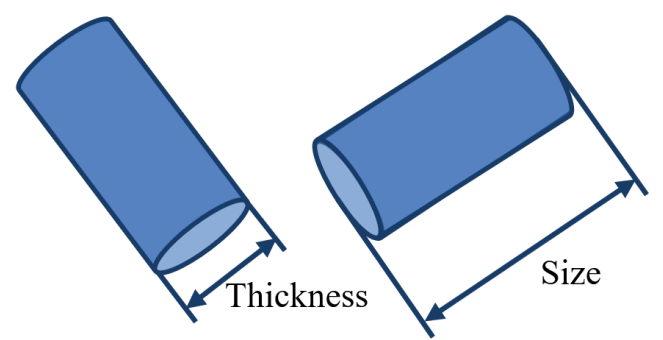

Figure 3 Determining the thickness and size of parts [3]

\section{Production manufacturability assessment methods}

\subsection{Boothroyd Dewhurst method}

The method was developed in the late 1970s. by Geoffrey Boothroyd at the University of Massachusetts in Amherst in cooperation with the University of Salford in England. The method contains eight principles aimed at: reducing the number of components, eliminating corrections, using self-positioning and self-embedding components, ensuring adequate access and unrestricted field of view, ensuring ease of assembling parts with looseness, minimizing the need for reorientation during the assembly, eliminating parts, that cannot be installed

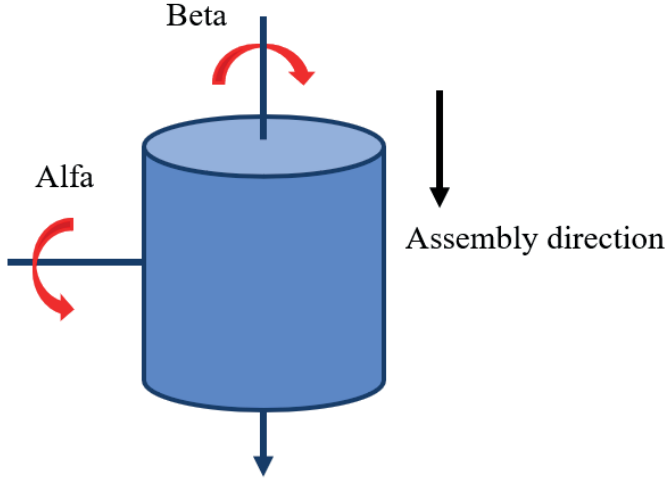

Figure 4 Determining alpha and beta angles [3]

incorrectly, maximizing symmetrical parts, if possible, or if not clearly asymmetrical. The method assumes that the part is a permanent or non-permanent element of the assembly process. A subassembly is considered as a part if it is added during the assembly. However, glues, fluxes, fillers, etc., used to connect parts are not considered parts. Each part has two parameters - thickness and size. The thickness is the length of the shortest side of the smallest cuboid that surrounds the element. If the element has a cylindrical or regular polygonal shape, e.g. a section with five or more sides, the thickness is defined as the radius of the smallest cylinder that surrounds the element (Figure 3). The size is the length of the longest side of the smallest cuboid that can surround the part. 


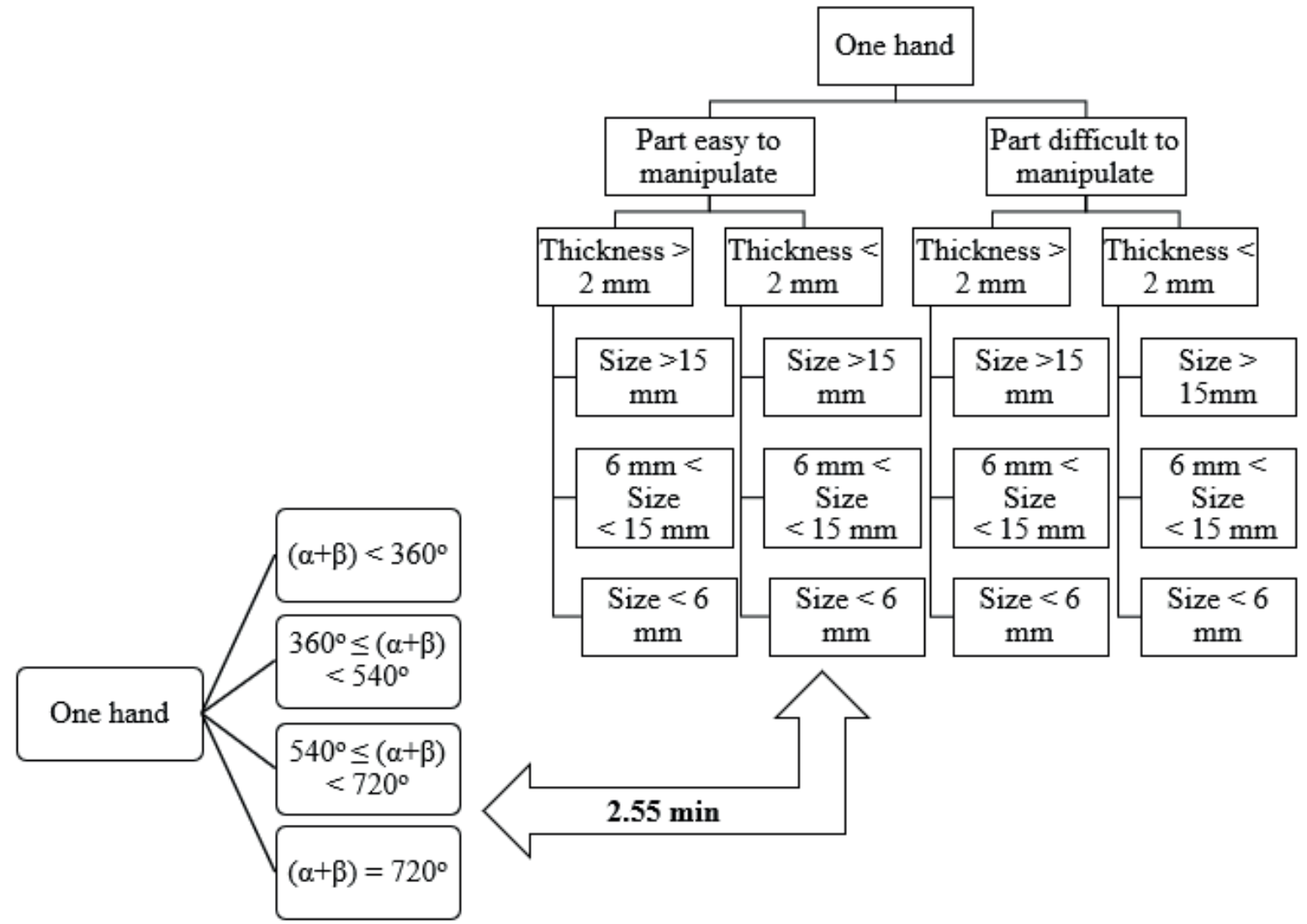

Figure 5 Diagram for determining the index of manipulation with one hand [17]

The next step is to evaluate the symmetry of the element and determine the number of degrees of rotation around both axes for proper orientation and alignment, Figure 4, [3].

BETA is the symmetry of the part relative to the insertion axis, i.e. the smallest rotation angle for correct insertion. ALFA is the symmetry of the part about the axis perpendicular to the insertion direction - the smallest angle between alternative insertion directions [3]. After determining the thickness, size, BETA and ALFA angles, the next step is to formulate the indexes of handling time and the time of inserting / assembling individual components. To this end, use schemes and tables prepared by Boothroyd and Dewhurst (Figure 5).

The total number of operations to assembly product is:

$L_{o}=l_{o 1+} l_{o 2}+\ldots . . l_{o i+\ldots . . .} l_{o n}$

where:

$l_{o i}$ - i-th assembly operation.

The total product assembly time is calculated as:

$T_{o}=\Sigma t_{o i}=I_{m a}+I_{m o}$

where:

$t_{o i}$ - duration of the i-th assembly operation,

$I_{m a}$ - part handling index, $I_{m o}$ - part assembly index.
Total costs of assembly product is:

$K_{o}=\Sigma k_{o i}$

where:

$l_{o i}$ - i-th assembly operation,

$k_{o i}$ - unit cost of i-th assembly operation [17].

When determining the time index for manipulation of a part, it should be determined whether manipulation can be performed: with one hand, one hand with an auxiliary handle, two hands, two hands with mechanical assistance. Knowing the assembly times, one can proceed to process analysis, e.g. whether one should reduce the number of assembled parts, replace them with other, more complex ones. Lowering the number of components of a product may increase their complexity and increase their manufacturing costs. The final product can be easy to assemble and expensive to process its components. This method is used to analyse manual assembly; separate variants of the method are used to analyse automatic assembly. The final stage is calculation of a sum of the number of operations, total operation time, total operation costs, theoretical minimum number of parts and the DFMA index illustrating the state of the product technology. The next stage of analysis is to check whether a given part can be eliminated. A diagram of the course of proceedings regarding the elimination of parts is given in Figure 6 (assessment of possibility for occurrence of several parts in the form of one whole). 


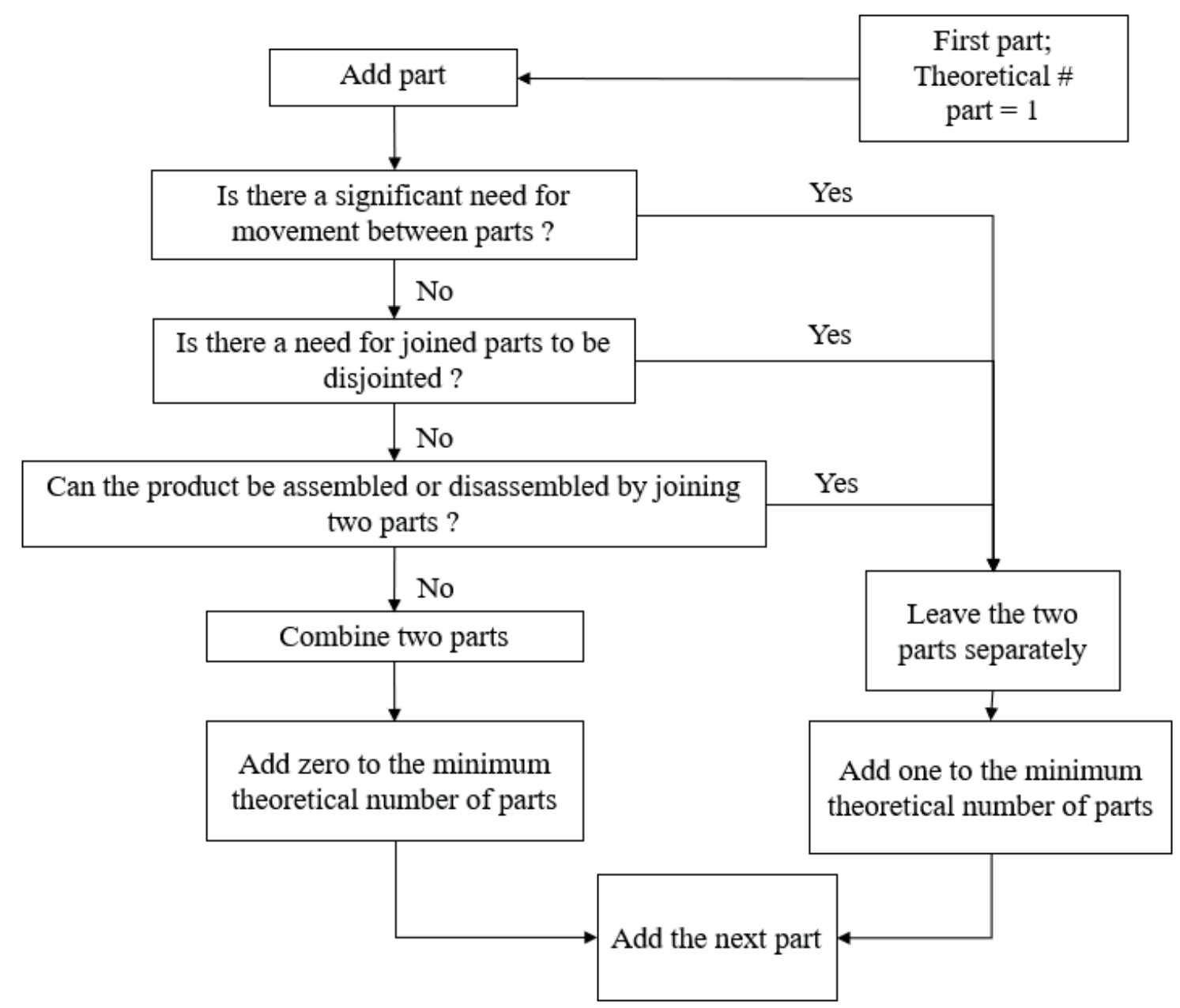

Figure 6 Design for Assembly $B$ \& D components elimination diagram [17]

The theoretical minimum number of parts is:

$C_{t}=C_{p e}-C_{a e}$

where:

$C_{p e}$ - number of parts before elimination analysis,

$C_{a e}$ - number of parts eliminated as part of the elimination analysis.

The final stage is determining the DFMA indicator, while considering the costs of the assembly operation being carried out:

$D F M A_{\text {index }}=\left(3 \cdot L_{0}\right) / T_{o}$,

for many parts, it can be assumed that: $L_{o}=A$ and where: $D F M A_{\text {index }}$-DFMA index,

$A$ - the number of parts necessary for the product to function (the study assumes that: $L_{o}=A=C_{t}$ ),

$T_{\mathrm{o}}$ - total product assembly time) [17].

\subsection{Lucas DFA method}

The method was developed in 1980 . by Lucas research teams and University of Hull researchers, [17]. The method is used to analyse manual or automatic assembly. In the Lucas DFA method, three indicators determine the measure of mounting difficulty. The procedure is as follows. The prepared project is subjected to functional analysis, which determines whether individual components are needed and what their functions are (Figure 7).

A feasibility analysis is then conducted consisting of manoeuvring analysis and assembly analysis. Data for analysis can be read for specific installation conditions from tables developed by the authors of the method [18].

The project effectiveness index $W_{e p}$, based on functional analysis, is determined by the formula:

$W_{e p}=\left[L_{k A} /\left(L_{k A+} L_{k B}\right)\right] 100 \%$,

where:

$L_{k A}$ - number of components A (fulfilling the functions of a product),

$L_{k B}$ - number of components B (characterized by a lack of product function e.g. rivets, washers) [18].

Based on the analysis carried out in this way, it is possible to combine some separate components into one whole, thereby reducing the number of individual components that make up the final product, change design solutions that eliminate components that do not fulfil 


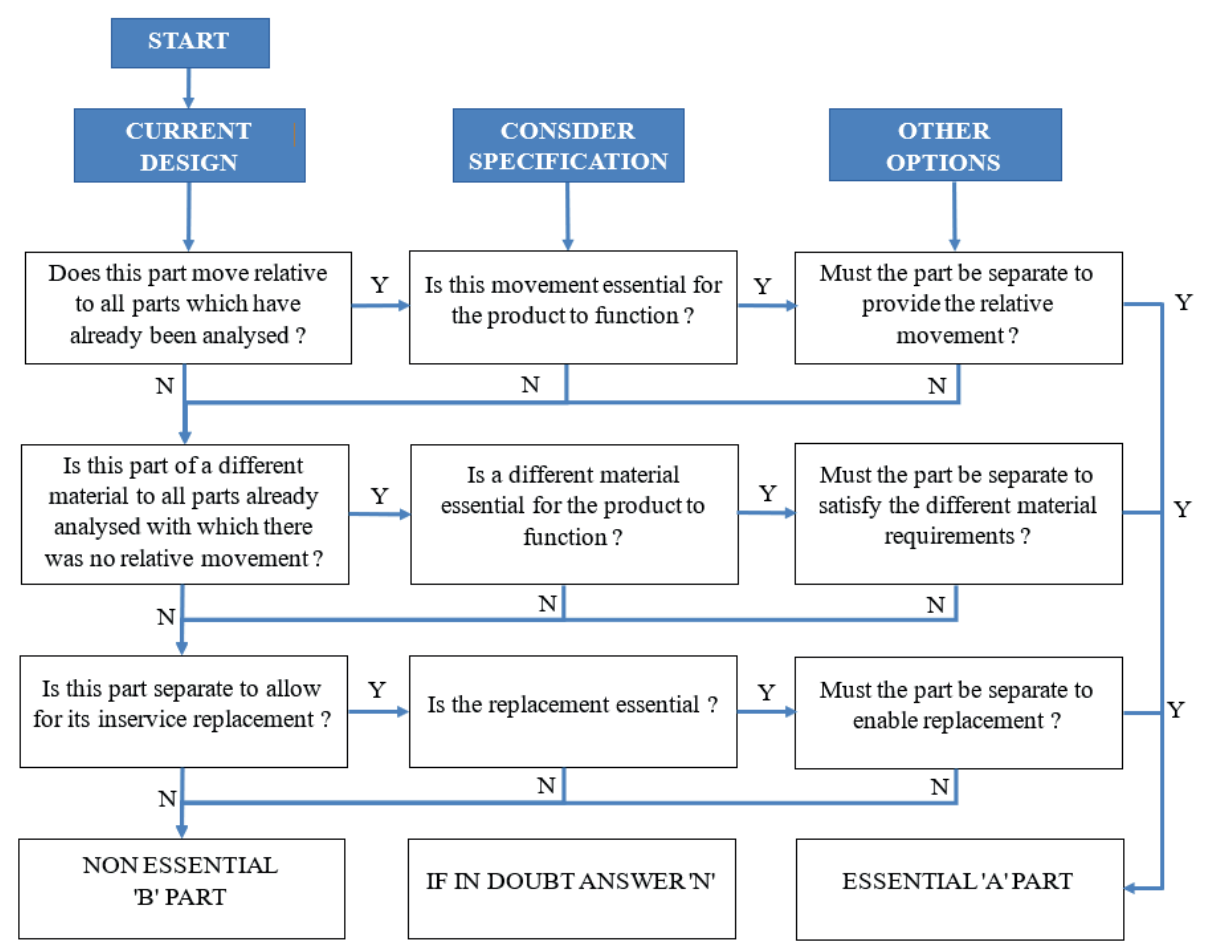

Figure 7 Diagram of functional analysis in LUCAS Design for Assembly [18]
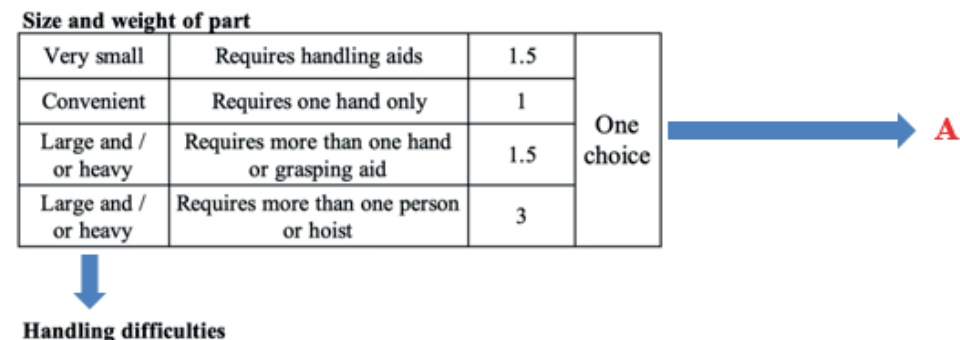

\begin{tabular}{|c|c|c|}
\hline Fragile & 0.4 & \multirow{8}{*}{$\begin{array}{l}\text { Select al } \\
\text { that are } \\
\text { relevant }\end{array}$} \\
\hline Flexible & 0.6 & \\
\hline Adherent & 0.5 & \\
\hline Tangle & 0.8 & \\
\hline Severely nest & 0.7 & \\
\hline Sharp/abrasive & 0.3 & \\
\hline Untouchable & 0.5 & \\
\hline $\begin{array}{l}\text { Gripping } \\
\text { problem }\end{array}$ & 0.2 & \\
\hline
\end{tabular}
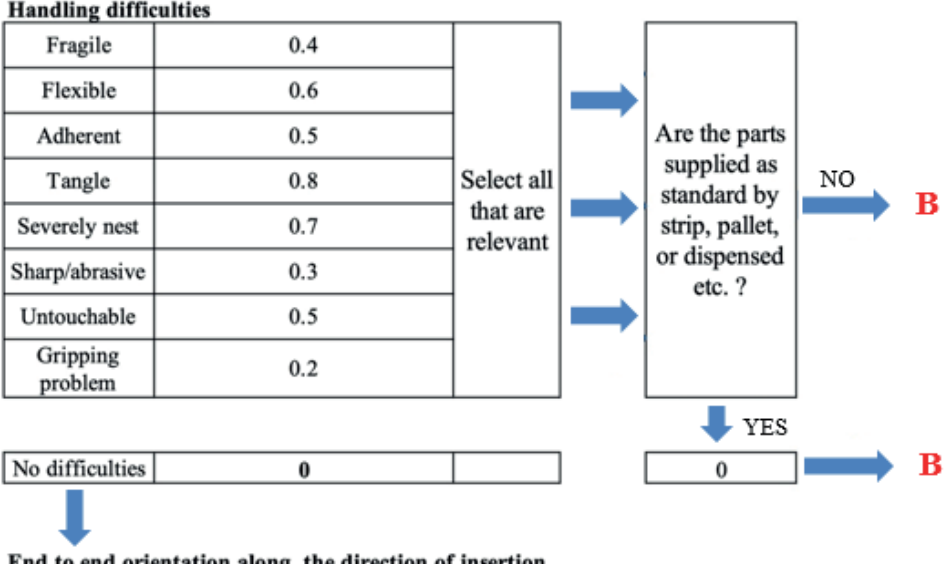

End to end orientation along the direction of insertion

\begin{tabular}{|c|c|c|}
\hline None required & 0 & \multirow{2}{*}{$\begin{array}{c}\text { One } \\
\text { choice }\end{array}$} \\
\hline Easy to see & 0.1 & \\
\hline Not easy to see & 0.5 & \\
\hline
\end{tabular}
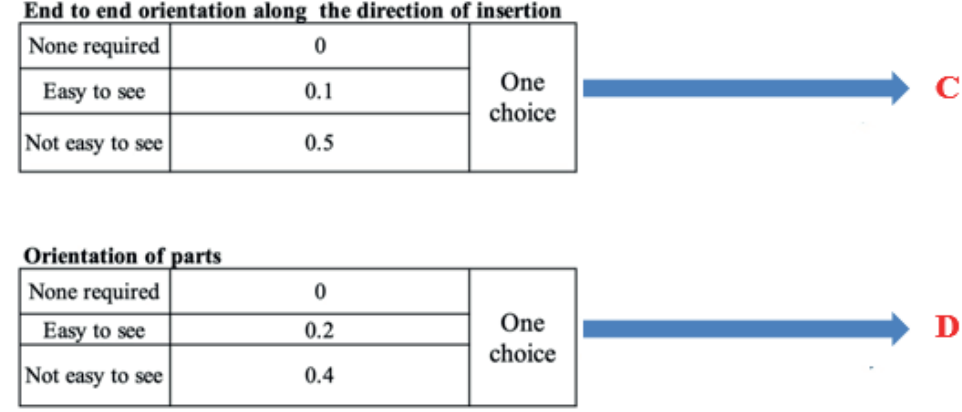

Handling Index $=\mathbf{A}+\mathbf{B}+\mathbf{C}+\mathbf{D}$

Figure 8 Manoeuvring analysis scoring diagram in LUCAS DFA [18-19] 


\section{START}

\section{Insertion process}
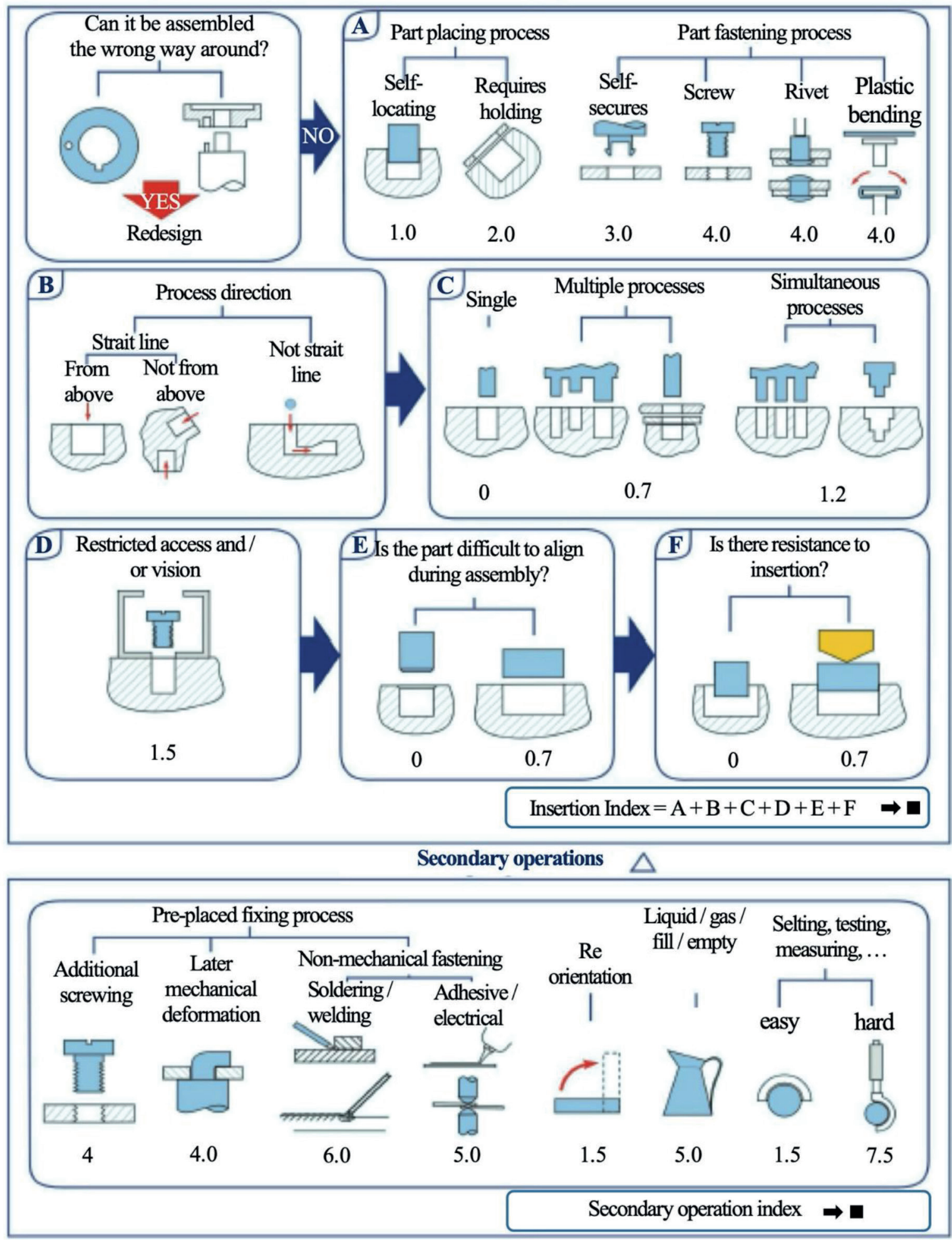

Figure 9 Assembly analysis scoring diagram in LUCAS DFA [18]

the function of the product. Then, an analysis is carried out consisting of an analysis of the displacement of the mounted components, their manoeuvring and the method of assembly itself. The manoeuvring assessment of the assembled product components is determined based on Figure 8.
Manoeuvring factor $W_{\text {man }}$ is given by the formula:

$W_{\text {man }}=I_{\text {man }} / L_{k A}$,

where $W_{\operatorname{man}}$ is the manoeuvring factor and 
$I_{\text {man }}=L_{p A}+L_{p B}+L_{p C}+L_{p D}$

where:

$I_{\text {man }}$ - manoeuvring index,

$L_{k A}{ }^{-}$number of type A parts.

Values of $L_{p A}, L_{p B}, L_{p C}, L_{p D}$ are specified from tables provided by the authors of the method [18].

The analysis also makes it possible to make structural changes to the product and its components improving the efficiency of assembly processes and the method of assembly technology designed (e.g. use of the special equipment to facilitate manoeuvring of the assembled component).

Another element of the technology assessment is assessment of the errors risk in individual assembly operations and impact of the adopted construction solutions on the labour intensity of individual assembly operations. Assessment of the assembly operations progress, from the feasibility point of view, is carried out based on Figure 9.

The formula describing results of the analysis of the $W_{\text {mon }}$ assemblability coefficient according to the Lucas DFA method is

$W_{\text {mon }}=\left(W_{m}+W_{d}\right) / L_{k A}$,

where:

$W_{m}$ - main activity indicator wherein, $W_{m}=L_{m A}+L_{m B}+L_{m C}+$ $L_{m D}+L_{m E}+L_{m F}$

$W_{d}$ - indicator of additional activities, values making up the $W_{m}$ and $W_{d}$ parameters are specified in tables provided by the authors of the method,

$L_{k A}$ - number of the type A parts [18-19].

\section{Conclusions}

The B\&D and Lucas DFA methods are methods developed for the needs of assembly operations in the conditions of mass production. By analysing the obtained values of assembly efficiency assessment parameters in both methods it is possible to:

- $\quad$ Reduce times, eliminate of errors, reduce the process costs.

- consider, in addition to assembly, many other various factors, e.g. availability of spare parts, mass production, production conditions in the form of equipment types, available assembly techniques, level of automation, scope of external cooperation orders, etc.

The conditions of modern production, striving to manufacture products tailored to the individual wishes of the customer, with the largest possible serial production of component parts causes the need to modify or develop new methods for analysing the product design technology. The assessment should consider many other factors, sales, servicing, spare parts availability, production series, types of equipment, available assembly techniques, level of automation, cooperative services, possibilities of using commercial components, technical culture of the crew, etc. The new methods developed should also be used for smaller series of manufactured products in the case of the production of a group of technologically similar products. A helpful action in the assessment of the structure is use of standardization of machining and assembly operations, which makes it easier to determine the times of performing those operations. The assessment of the construction arouses the creativity of designers, the course of action can be carried out for the product, its components such as assemblies, subassemblies, etc.

\section{References}

[1] ABDUllaH, A., POPPLEWELL, K., PAGE, C. J. A review of the support to tools for the process of assembly method selection and assembly planning. International Journal of Production Research [online]. 2003, 41(11), p. 2391-2410 [accessed 2020-01-27]. ISSN 1366-588X. Available from: https://doi.org/10.1080/002075431000087265

[2] MATUSZEK, J. Production engineering /Inzynieria produkcji (in Polish). Bielsko-Biala: Wydawnictwo Politechniki Lodzkiej Filii, 2020. ISBN 83-87087-97-1, p. 83-109.

[3] MATUSZEK, J., SENETA, T. Algoritmization of the new product implementation process in the conditions of mass production / Algorytmizacja procesu wdrazania nowegp produktu w warunkach wielkoseryjnej produkcji (in Polish). Mechanik [online]. 2016, 7, p. 755-757 [accessed 2020-01-27]. ISSN 0025-6552. Available from: http://www.mechanik. media.pl/pliki/do_pobrania/artykuly/22/konferencja_158.pdf

[4] Advanced product quality planning (APQP) and control plan. Reference manual (company standard). AAIG - Chrysler Corporation, Ford Corporation, General Motors Corporation. Adare Carvin. Unit 1, Trade Link, Western Ave, West Thurrock, Grays, Essex England, 1995.

[5] BOOTHROYD, G., DEWHURST, P. Design for assembly. Designers Handbook. 1938. ISBN 0-903608-35-9.

[6] KNIGHT, W. A., BOOTHROYD, G. Fundamentals of metal machining and machine tools. 3. ed. Taylor and Francis Group: CRC Press, 2005. ISBN 978-157-444-659-3.

[7] GREGOR, M., MATUSZEK, J. Production systems development trends / Tendencje projektowania systemow produkcyjnych (in Polish). Mechanik [online]. 2013, 7, p. 231-238 [accessed 2020-01-27]. ISSN 0025-6552. Available from: http://www.mechanik.media.pl/pliki/do_pobrania/artykuly/2/4924_231_238.pdf 
[8] MATUSZEK, J., SENETA, T.: Evaluation of design manufacturability in new product production launches by Lucas DFA method. Mechanik [online]. 2017, 7, p. 755-757 [accessed 2020-01-27]. Available from: http://www.mechanik.media.pl/ pliki/do_pobrania/artykuly/22/2017_07_s0523_eng.pdf

[9] CHANG, T. C. Expert process planning for manufacturing. NY: Addison-Wesley Publishing Company, Inc., 1990. ISBN-13: 978-0201182972.

[10] EGAN, M. Design for assembly in the product development process-a design theory perspective. Thesis for the degree of Licenciate of Engineering. Marina del Rey, 1997. ISBN 99-248946-85.

[11] LIBERS, A., SREPPEL, A., SCHUTTERT, M., KALS, H. Part classification for variant cost estimation. In: 4th International Conference on Sheet Metal: proceedings. Vol. 2. SheMet, 1996. ISBN 903-650-804-5, p. 167-178.

[12] JAMES, A., GANDHI, O. P., DESHMUKH, S. G. Development of methodology for the disassemblability index of automobile system using a structural approach. Proceedings of the Institution of Mechanical Engineers, Part D: Journal of Automobile Engineering [online]. 2016, 231(4), p. 516-535 [accessed 2020-01-27]. ISNN 0954-4070. Available from: https://doi.org/10.1177/0954407016656311

[13] BREYFOGLE, F. W. Implementing Six Sigma. 2. ed. New Jersey: John Wiley and Sons, 2003. ISBN 978-0471265726.

[14] SHETTY, D., ALI, A. A new design tool for DFA/DFD based on rating factors. Assembly Automation [online]. 2015, 35(4), p. 348-357 [accessed 2020-01-27]. ISSN 0144-5154. Available from: https://doi.org/10.1108/AA-11-2014-088

[15] PAN, L., CHO, H. J., PARK, J. I. Study on the design factors affecting the operating actions that can be used easily at the design stage. Advanced Materials Research [online]. 2015, 1061-1062, p. 712-715 [accessed 2020-01-27]. ISSN 1662-8985. Available from: https://doi.org/10.4028/www.scientific.net/AMR.1061-1062.712

[16] SHUKOR, A. I. A., ADAM, A. Evaluation of design efficiency using Boothroyd Dewhurst Method for PCB drilling machine product. International Journal of Simulation Systems. Science and Technology [online]. 2018, 19(5), 4.1-4.8 [accessed 2020-01-27]. ISSN 1473-8031, eISSN 1473-804x. Available from: https://doi.org/10.5013/IJSSST.a.19.05.04

[17] MATUSZEK, J., KOLOSOWSKI, M., KROKOSZ-KRYNKE, Z. Cost accounting for engineers / Rachunek kosztow dla inzynierow (in Polish). Warszawa: Polskie Wydawnictwo ekonomiczne, 2014. ISBN 978-83-208-2104-8, p. $215-247$.

[18] SWIFT, K., BROWN, N. Design for Assembly / manufacturing analysis practitioner's manual. Version 10.5. Great Britain: University of Hull, 1994. ISBN 978-0-13-516569-0, p. 116-138.

[19] DADO, M., KOTEK, L., HNILICA, R., TUMA, Z. The application of virtual reality for hazard identification training in the context of machinery safety: a preliminary study. Manufacturing Technology [online]. 2018, 18(5), p. 732-736 [accessed 2020-01-27]. ISSN 1213-2489. Available from: https://doi.org/10.21062/ujep/168.2018/a/1213-2489/MT/18/5/732 